4. Winkler G, Salamon F, Salamon D, Speer G, Simon K, Cseh K (1998) Elevated serum tumor necrosis factor-alpha levels can contribute with the insulin resistance in Type 2 (non-insulin-dependent) diabetes and obesity. Diabetologia 41: 680-682

5. Zhu XP, Satoh J, Muto G, et al. (1996) Improvement of glucose tolerance with immunomodulators on type 2 diabetic animals. Biotherapy 9: 189-197
6. Matsuzaki T, Yamazaki R, Hashimoto S, Yokokura T (1997) Antidiabetogenic effects of an oral administration of Lactobacillus casei in a non-insulin-dependent diabetes mellitus (NIDDM) model using KK-Ay mice. Endocr J 44: 357-365

7. Winkler G, Dworak O, Salamon F, Salamon D, Speer G, Cseh K (1998) Increased interleukin-12 plasma concentrations in both, insulin-dependent and non-insulin-dependent diabetes. Diabetologia 41: 488

\section{D-glucose transport and utilization in pituitary adenoma cells transfected with glucokinase gene}

\begin{abstract}
Dear Sir,
In their recent and interesting article published in Diabetologia [1], Motoyoshi et al. reported that AtT20HI-GK-1 cells display a $\mathrm{Km}$ close to $2.4 \mathrm{mmol} / \mathrm{l}$ and a $\mathrm{V}_{\max }$ close to $1.5 \mathrm{mmol}$. $\min ^{-1} \cdot \mathrm{mg}$ protein ${ }^{-1}$ for tritiated 3-O-methyl-D-glucose uptake. After submission of a first version of the present letter and in the light of my comments, the authors produced an erratum indicating that in the third column of Table 1 the unit for $\mathrm{V}_{\max }$ should $\mathrm{read} \mathrm{mmol} \cdot \mathrm{min}^{-1} \cdot$ litre cell space ${ }^{-1}$. Assuming an intracellular space close to $5 \mu \mathrm{l} / \mathrm{mg}$ protein, the $\mathrm{V}_{\max }$ would thus be close to $7.5 \mathrm{nmol} \cdot \mathrm{min}^{-1} \cdot \mathrm{mg}$ protein ${ }^{-1}$, a value representing only 5 per million of that first reported by the authors. The close-to-maximum rate of $\mathrm{D}-\left[5-{ }^{3} \mathrm{H}\right]$ glucose utilization by these cells, at a D-glucose concentration of $25 \mathrm{mmol} / \mathrm{l}$, does not exceed $480 \mathrm{nmol} \cdot 2 \mathrm{~h}^{-1} \cdot \mathrm{mg} \operatorname{protein}^{-1}$ or $4 \mathrm{nmol}$. $\min ^{-1} \cdot \mathrm{mg}$ protein ${ }^{-1}$, a value representing less than $60 \%$ of the calculated rate of 3-O-methyl-D-glucose uptake at the same hexose concentration (about $6.8 \mathrm{nmol} \cdot \mathrm{min}^{-1} \cdot \mathrm{mg}$ pro-
\end{abstract}

Corresponding author: Prof. W. J. Malaisse, Laboratory of Experimental Medicine, Brussels Free University, 808 Route de Lennik, B-1070 Brussels, Belgium tein $\left.^{-1}\right)$. Yet, these cells, which contain about $10^{4}$ times less insulin per mg protein $(62 \mu \mathrm{U} / \mathrm{mg}$ protein $)$, than normal islets (at least $1.0 \mathrm{U} / \mathrm{mg}$ protein), are virtually unable to respond by increasing rates of insulin secretion to a rise in D-glucose concentration in the $0.1-25.0 \mathrm{mmol} / \mathrm{l}$ range. These findings raise serious concern. They indeed suggest that the rate of D-glucose transport would be largely sufficient to allow full expression of glucokinase activity. And, indeed, the above-mentioned rate of $\mathrm{D}-\left[5-{ }^{3} \mathrm{H}\right]$ glucose utilization is not vastly different from the summed activities of hexokinase and glucokinase in cytoplasmic fractions of these cells.

The following question comes, therefore, to mind. How could D-glucose transport become rate-limiting for the expression of hexokinase isoenzyme activity and, hence, insulin release in these cells?

Yours sincerely,

W.J. Malaisse

\section{Reference}

1. Motoyoshi S, Shirotani T, Araki E et al. (1998) Cellular characterization of pituitary adenoma cell line (AtT20 cell) transfected with insulin, glucose transporter type 2 (GLUT2) and glucokinase genes: insulin secretion in response to physiological concentrations of glucose. Diabetologia 41: 1492-1501

\title{
Erratum
}

Diabetologia (1998) 41: 1492-1501

\section{Cellular characterization of pituitary adenoma cell line (AtT20 cell) transfected with insulin, glucose transporter type 2 (GLUT2) and glucokinase genes. Insulin secretion in response to physiological concentrations of glucose}

\author{
S. Motoyoshi, T. Shirotani, E. Araki, K. Sakai, K. Kaneko, H. Motoshima, K. Yoshizato, A. Shirakami, H. Kishikawa, \\ M.Shichiri \\ Department of Metabolic Medicine, Kumamoto University School of Medicine, Kumamoto, Japan
}

On page 1496 , Table 1 , third column, the unit of $\mathrm{Vmax}$ should $\mathrm{read}\left(\mathrm{mmol} \cdot \mathrm{min}^{-1} \cdot\right.$ litre cell $\left.\mathrm{space}^{-1}\right)$ instead of $\left(\mathrm{mmol} \cdot \mathrm{min}^{-1} \cdot \mathrm{mg}\right.$ protein $\left.{ }^{-1}\right)$. 